\title{
Implementasi Program Pendewasaan Usia Perkawinan (PUP) Di Kecamatan Amuntai Selatan Kabupaten Hulu Sungai Utara
}

\author{
${ }^{1}$ Munawarah \\ ${ }^{1}$ Sekolah Tinggi Ilmu Administrasi Amuntai \\ email : noormunawarah9@gmail.com
}

\begin{abstract}
Abstrak
Pernikahan ideal adalah seorang perempuan menikah pada usia minimal 21 tahun sedangkan laki-laki minimal 25 tahun. Tujuan Penelitian untuk mengetahui Implementasi PUP, Penelitian ini menggunakan pendekatan kualitatif dengan analisis reduksi data, penyajian data penarikan kesimpulan. Hasilnya menunjukkan bahwa implementasi Program PUP Pertama, karakteristik masalah yang dihadapi oleh program PUP ini adalah permasalahan pernikahan dini yang cenderung sulit untuk diatasi. Kedua, karakteristik kebijakan yang masih menimbulkan kebingungan di masyarakat. Ketiga, lingkungan kebijakan yang belum mendukung sepenuhnya terhadap program. Faktor-faktor penghambat implementasi program diantaranya keanekaragaman sifat kelompok sasaran, ketidakjelasan isi program, kurangnya alokasi dana, partisipasi masyarakat kurang serta rendahnya sosial ekonomi dan kemajuan teknologi. Kemudian upaya untuk mengatasi faktor penghambat yaitu penyamaan pendapat tentang usia nikah, adanya teknik penyampaian dan kerjasama, alokasi dana untuk PIK-R dan BKR, penyelenggaraan partisipasi masyarakat di PIK-R dan BKR. Upaya peningkatan sosial ekonomi masyarakat.Untuk meningkatkan implementasi PUP di Kecamatan Amuntai Selatan Kabupaten Hulu Sungai Utara maka disarankan untuk Kepala DPPKB Kabupaten Hulu Sungai Utara serta BKPB Kecamatan Amuntai Selatan agar lebih meningkatkan penyuluhan dan alokasi dana untuk Program PUP. Instansi-instansi terkait agar bisa saling bersinergi dan koordinasi dalam mengatasi pernikahan dini. Masyarakat diharapkan lebih mengenal lagi tentang PUP melalui partisipasi di PIK-R dan BKR di setiap desa.
\end{abstract}

Kata kunci; Kebijakan, Perkawinan, Menikah Muda.

\begin{abstract}
The ideal marriage is for a woman to get married at the minimum age of 21 years while for a boy at least 25 years. The research objective was to determine the implementation of PUP. This study used a qualitative approach with data reduction analysis, presenting data to draw conclusions. The results show that the implementation of the PUP Program. First, the characteristic of the problems faced by the PUP program is the problem of early marriage which tends to be difficult to overcome. Second, the characteristics of policies that still cause confusion in society. Third, the policy environment that has not fully supported the program. The factors inhibiting the implementation of the program include the diversity of the nature of the target group, unclear program content, lack of fund allocation, lack of community participation and low socio-economic and technological progress. Then efforts to overcome the inhibiting factors are the same opinion on the age of marriage, the existence of delivery and collaboration techniques, the allocation of funds for PIK-R and BKR, organizing community participation in PIK-R and BKR. Efforts to improve the community's socio-economy. To improve the implementation of PUP in Amuntai Selatan District, Hulu Sungai Utara Regency, it is recommended that the Head of the DPPKB Hulu Sungai Utara Regency and the BKPB of Amuntai Selatan District to further increase the education and allocation of funds for the PUP Program. Related agencies in order to synergize and coordinate with each other in overcoming early marriage. The community is expected to know more about PUP through participation in PIK-R and BKR in each village.
\end{abstract}

Keywords; Public Policy, Marriage, Young Marriage 


\section{PENDAHULUAN}

Kasus Pernikahan dini di Asia Tenggara terdapat sekitar 10 juta anak usia di bawah 18 tahun, di Indonesia terdapat 50 juta penduduk dengan rata-rata usia perkawinan 19,1 tahun. Provinsi Kalimantan Selatan menjadi provinsi dengan jumlah perkawinan anak tertinggi di Indonesia yaitu 39,53 persen (dari jumlah seluruh perkawinan), sementara Daerah Istimewa Yogyakarta terendah dengan 11,07 persen (CNN Indonesia, 2019). Data ini dihimpun oleh Badan Pusat Statistik (BPS) dan dirilis oleh Kementerian Pemberdayaan Perempuan dan Perlindungan Anak (KPPPA). terdapat 23 provinsi di Indonesia yang angka persentase perkawinan anaknya di atas angka perkawinan anak Indonesia, yakni 25,71 persen. Angka perkawinan anak Indonesia sendiri merupakan yang tertinggi ke-7 se-dunia dan yang tertinggi ke2 se-ASEAN. Setelah Kalsel, empat provinsi lainnya dengan angka perkawinan anak paling tinggi adalah Kalimantan Tengah (39,21 persen), Kepulauan Bangka Belitung (37,19 persen), Sulawesi Barat (36,93 persen), dan Sulawesi Tenggara (36,74 persen). Perkawinan anak di kelompok 10-15 tahun atau usia paling dini mencapai 34,5 persen, kemudian disusul 39,2 persen angka perkawinan di usia 16 tahun, dan 26,3 persen di usia 17 tahun.

Setidaknya ada tiga alasan mengapa upaya mendewasakan usia perkawinan di Indonesia menjadi sesuatu yang urgen. Pertama, sekarang ini banyak kasus-kasus ketidakharmonisan berkeluarga yang berujung pada perceraian karena pasangan suami isteri belum cukup umur untuk memikirkan/memecahkan persoalan-persoalan rumah tangga yang cukup rumit dan membutuhkan tidak saja kedewasaan berpikir dan kemampuan menahan diri, tetapi juga kesiapan mental dan ekonomi sebagai bagian terpenting untuk mampu membangun keluarga kecil bahagia dan sejahtera. Sementara ketidakharmonisan sebuah keluarga akan membawa dampak pada terjadinya kasus-kasus Kekerasan Dalam Rumah Tangga (KDRT), timbulnya perselingkuhan, kekerasan atau penelantaran terhadap anak, terganggunya tumbuh kembang anak, dan permasalahan sosial lainnya.

Kedua, dengan pernikahan di usia dini, perempuan memiliki rentang masa reproduksi lebih panjang yang secara langsung maupun tidak langsung akan mempengaruhi jumlah anak yang akan dilahirkan. Sementara ditinjau dari sudut pandang demografi, jumlah penduduk di Indonesia saat ini menurut Sensus Penduduk 2010 sudah sangat besar, yakni mencapai 237,6 juta jiwa dengan laju pertumbuhan penduduk $1,49 \%$ per tahun atau terjadi pertambahan sekitar 4 juta jiwa per tahun. Kondisi ini jelas akan memperberat beban pembangunan yang selama ini diupayakan pemerintah.

Program Pendewasaan Usia Perkawinan (PUP) di Kabupaten Hulu Sungai Utara terkhusus di Kecamatan Amuntai Selatan belum membuahkan hasil yang maksimal. Hal ini disebabkan oleh beberapa fenomena masalah yang nampak di lapangan serta data yang diperoleh penulis, diantaranya sebagai berikut masih tingginya jumlah perkawinan di bawah usia ideal berdasarkan program pendewasaan usia perkawinan (minimal menikah pada 21 tahun untuk perempuan dan 25 tahun untuk laki-laki) di kec. Amuntai Selatan, hal ini terbukti dari data 3 tahun terakhir dari Kantor Urusan Agama (KUA) Kec. Amuntai Selatan, yaitu Tahun 2017 (248 Perkawinan) : Laki-laki 106 orang (42,74\% dari 248 orang) dan Perempuan 98 orang (39,51\% dari 248 orang), Tahun 2018 (233 Perkawinan) : Laki-laki 92 orang (39,48\% dari 233 orang) dan Perempuan 97 orang (41,63\% dari 233 orang). Tahun 2019 (216 Perkawinan) : Laki-laki 96 orang (44,44\% dari 216 orang) dan Perempuan 79 orang (36,57\% dari 216 orang).

Masih rendahnya intensitas penyuluhan yang dilakukan oleh Penyuluh KB Amuntai Selatan tentang Program Pendewasaan Usia Perkawinan (PUP) ke desa-desa (30 desa) di Amuntai Selatan, hal ini terbukti dari data frekuensi penyuluhan 3 tahun terakhir dari Balai Penyuluh Keluarga Berencana (BPKB) Amuntai Selatan, yaitu sebagai berikut. Tahun 2017 : tidak adanya penyuluhan tentang Program Pendewasaan Usia Perkawinan (PUP) Tahun 2018 : dalam 1 tahun hanya ada 4 kali penyuluhan tentang 
Program Pendewasaan Usia Perkawinan (PUP), Tahun 2019: dalam 1 tahun hanya ada 4 kali penyuluhan tentang Program Pendewasaan Usia Perkawinan (PUP)

Sempitnya cakupan desa sasaran penyuluhan penyuluhan yang dilakukan oleh Penyuluh KB Amuntai Selatan tentang Program Pendewasaan Usia Perkawinan (PUP) di Amuntai Selatan hal ini terbukti dari data frekuensi penyuluhan 3 tahun terakhir dari Balai Penyuluh Keluarga Berencana (BPKB) Amuntai Selatan, yaitu sebagai berikut. Tahun 2017 : Tidak ada penyuluhan tentang Program Pendewasaan Usia Perkawinan (PUP) Tahun 2018 : 2 kali di desa Kayakah dan 2 kali di desa Simpang Empat.. Tahun 2019 : sama dengan tahun sebelumnya yaitu 2 kali di desa Kayakah dan 2 kali di desa Simpang Empat.

\section{METODE}

Penelitian ini menggunakan pendekatan kualitatif dengan penelitian deskriftif. Jenis data yang digunakan adalah data primer dan data sekunder, teknik pengumpulan datanya menggunakan observasi, wawancara dan dokumentasi. Sumber data diambil melalui informan yang berjumlah 15 orang secara purposive. Teknik analisis data dengan reduksi data, penyajian data dan penarikan kesimpulan. Uji kredibilitas data dengan meningkatkan ketekunan, triangulasi, menggunakan bahan referensi dan mengadakan member check.

\section{HASIL DAN PEMBAHASAN}

Implementasi merupakan sebuah tahap yang paling penting dalam proses kebijakan publik. Suatu program kebijakan harus di implementasikan agar mempunyai dampak dan tujuan yang diinginkan. Dalam pengimplementasian sebuah program maka diperlukannya sebuah strategi yang tersistematis, seperti halnya program yang dikeluarkan oleh Badan Kependudukan dan Keluarga Berencana Nasional (BKKBN) yaitu program Pendewasaan Usia Perkawinan (PUP) yang target sasarannya adalah para remaja.

\section{Karakteristik Masalah}

Salah satu tujuan kebijakan publik dibuat adalah mengatasi permasalahan-permasalahan yang ada di masyarakat. Seperti halnya program Pendewasaan Usia Perkawinan (PUP) ini diimplementasikan dengan harapan dapat menekan angka pernikahan dini dengan cara meningkatkan usia perkawinan minimal 21 tahun untuk perempuan dan minimal 25 tahun untuk laki-laki.

Tingkat kesulitan teknis dari masalah yang dihadapi oleh program Pendewasaan Usia Perkawinan (PUP) ini adalah Pernikahan Dini yang sekarang tidak terlalu sulit untuk dihadapi. Namun, masalah teknis yang biasanya terjadi dalam implementasi program PUP ini adalah teknik sosialisasi dan penyuluhan yang belum sepenuhnya diterima dan berhasil kepada masyarakat. Terkadang ada masyarakat yang mudah untuk mengerti dan ada juga yang sulit mengerti terhadap suatu program yang disampaikan, hal ini disebabkan oleh tingkat pemahaman oleh setiap masyarakat berdasarkan tingkat pendidikannya

Masalah yang dihadapi oleh program PUP ini adalah Pernikahan yang belum ideal untuk menikah dikarenakan belum mencapai umur 21 tahun untuk perempuan dan 25 tahun untuk laki-lakinya. Masalah ini termasuk sulit untuk diatasi, hal ini disebabkan adanya perbedaan pandangan terhadap usia nikah. Pemerintah pemerintah melalui Badan Kependudukan dan Keluarga Berencana Nasional (BKKBN) menganggap pernikahan yang tidak ideal ini sebuah masalah yang serius karena akan berdampak pada 
kesehatan si ibu yang hamil serta kondisi psikis yang belum stabil untuk berumahtangga, oleh sebab itu BKKBN menganjurkan untuk menikah di usia yang matang dan ideal yaitu minimal 21 tahun untuk perempuan dan 25 tahun untuk laki-laki. Sedangkan dari pandangan sebagian masyarakat yang beranggapan usia menikah itu tidak terlalu menjadi sebuah persoalan yang berarti, hal ini didukung adanya Undang-Undang Nomor 16 Tahun 2019 tentang perubahan atas Undang-Undang Nomor 1 Tahun 1974 tentang Perkawinan pasal 7 ayat 1 yang berbunyi :Perkawinan hanya diizinkan

Tingkat kemajemukan (keanekaragaman) kelompok sasaran dalam program Pendewasaan Usia Perkawinan di Kecamatan Amuntai Selatan adalah beraneka ragam macam sifat, watak dan tingkat pemahamannya. Para remaja dan orang tua biasanya berbeda pendapat dalam memahami sesuatu hal, diakibatkan berbedanya zaman dan tingkat pendidikan, contohnya ketika si remaja memiliki tingkat pendidikan yang cukup, namun berbeda dari orang tuanya yang berpendidikan yang rendah, hal ini menyebabkan adanya perbedaan pendapat dan tingkat pemahaman terhadap program PUP ini. Mayoritas di Kecamatan Amuntai Selatan adalah beretnis Banjar, namun hal ini tidak menutup kemungkinan bahwa dalam 1 etnis yang sama ini tidak timbul sebuah perbedaan pandangan. Kemudian dari data dapat diketahui bahwa masyarakat di Amuntai Selatan adalah mayoritas beragama Islam, dimana hal tidak bisa menyatakan bahwa masyarakat di Amuntai Selatan sama dalam berpendapat dan berpandangan terhadap program PUP ini, contohnya ada sebagian masyarakat yang beranggapan bahwa lebih baik cepat nikah karena dapat menghindari perbuatan zina dan ada sebagian masyarakat lagi yang beragama Islam tidak perlu tergesa-gesa untuk nikah, apabila sudah siap dari faktor ekonomi, psikis dan kesehatannya baru nikah. Dari beberapa hasil ini tidak dapat disimpulkan bahwa kelompok sasaran program PUP di Amuntai Selatan adalah Homogen dan malah lebih ke arah Heterogen, dimana tingkat pemahaman dari anggota kelompok sasaran terhadap suatu program relatif berbeda, sehingga dapat disimpulkan bahwa proses implementasi program Pendewasaan Usia Perkawinan (PUP) di Kecamatan Amuntai Selatan masih belum optimal dikarenakan kelompok sasarannya adalah Heterogen, dimana tingkat pemahaman anggota kelompok sasaran berbeda-beda.

\section{Karakteristik Kebijakan}

Kejelasan isi dari program Pendewasaan Usia Perkawinan (PUP) ini sudah dapat dimengerti oleh sebagian masyarakat secara sederaha, seperti menunda nikah sampai saat usia sudah ideal dan sebagian masyarakat masih belum terlalu paham alasan mengapa harus menunda usia nikah jika sudah ada Undang-Undang Perkawinan. Kemudian masih banyak masyarakat yang tidak mengetahui fase program Pendewasaan Usia Perkawinan (PUP) diantaranya (1) masa menunda perkawinan dan kehamilan, (2) masa menjarangkan masa kehamilan, (3) masa mengakhiri kehamilan. Sebagian dari masyarakat hanya mengetahui bahwa program PUP itu sekedar menunda perkawinan.

Menunda perkawinan ke usia yang lebih matang akan mengurangi resiko-resiko baik dari segi ekonomi misalnya ketidakpastian penghasilan suami karena terlalu muda menikah, kemudian dari segi sosial budaya, misalnya tingginya resiko KDRT dan perceraian. Dari segi kesehatannya misalnya tingginya potensi keguguran karena rahmi ibu yang menikah dan hamil dini belum sempurna. Selain itu dari segi Administrasi, bahwa pasangan yang menikah dibawah umur ataupun yang terlalu dini sulit untuk mengurus keperluan administrasi anaknya kelak.

Keterpautan dan dukungan antara institusi pelaksana dalam program Pendewasaan Usia Perkawianan (PUP) di Kecamatan Amuntai Selatan dapat disimpulkan bahwa Implementor yaitu Dinas Pengendalian Penduduk dan Keluarga Berencana (DPPKB) Kabupaten dan Balai Penyuluhan Keluarga Berencana (BPKB) Kecamatan Amuntai Selatan sudah bekerja sama dan berkoordinasi dengan berbagai instansi terkait seperti Dinas Kesehatan Kabupaten Hulu Sungai Utara, Puskesma Kecamatan Amuntai Selatan, Kementerian Agama Kabupaten Hulu Sungai Utara, Kantor Urusan Agama (KUA) Kecamatan Amuntai Selatan, Dinas Perlindungan Perempuan dan Anak (DPPA) Kabupaten Hulu Sungai Utara, 
Dinas Pendidikan Kabupaten Hulu Sungai Utara, Majelis Ulama Indonesia (MUI) Kabupaten Hulu Sungai Utara, serta dari seluruh Pihak Pemerintahan Desa di Kecamatan Amuntai Selatan.

\section{Lingkungan Kebijakan}

Lingkungan kebijakan juga akan mempengaruhi proses implementasi kebijakan. Seperti halnya pada program Pendewasaan Usia Perkawinan (PUP) ini, maka harus pelaksana program harus mengetahui dan memperhitungkan lingkungan kebijakannya sehingga dapat memengaruhi keberhasilan implementasi.

Kondisi sosial ekonomi masyarakat dan kemajuan teknologinya dapat diketahui bahwa masyarakat di Kecamatan Amuntai Selatan (3 desa sampel : Desa Kayakah, Desa Simpang Empat, Desa Jumba) ratarata masyarakatnya masih berekonomi rendah dan bermata pencaharian pokoknya sebagai petani. Kemudian untuk kemajuan teknologinya dapat diketahui bahwa jaringan internet sudah menjangkau masyarakat di sana, tapi untuk kepemilikian Handphone canggih seperti Android hanya sebagian masyarakat saja yang memiliki seperti para pemuda atau remaja namun tidak semua orang memilkinya, padahal dalam upaya mensosialisasikan program melalui teknologi informasi dan komunikasi lebih efisisen dan efektif dibandingkan dengan cara yang konvensional. Dari hasil observasi masyarakat dengan tingkat berpendidikan rendah serta disusul tingkat pekerjaan yang rendah, beberapa orang dari masyarakat tidak terlalu memerdulikan usia ideal dalam menikah, kalau si remaja terutama perempuan, ketika sudah tidak bisa melanjutkan pendidikan lagi, maka orangtuanya lebih memilih itu menikahkan anaknya lebih cepat karena alasan dapat mengurangi tanggungan keluarga ketika sudah menjadi tanggungan suaminya. Kemudian dalam upaya menjarangkan masa kehamilan untuk tidak terlalu dekat masa perbedaan umur dari anak 1 ke anak ke 2 itu supaya minimal beda umur 5 tahun, dalam observasi peneliti bahwa masyarakat di Amuntai Selatan masih banyak yang memilki anak yang lebih dari 2 dan jarak umur antar anak sangat dekat. Selain itu dalam masa mengakhiri kehamilan pun dirasa masyarakat belum semuanya mampu untuk mengakhiri masa kehamilan atau berhenti memiliki anak di 35 tahun dikarenakan mereka masih percaya di umur itu masih dianggap sehat dan aman untuk hamil lagi, padahal jika mereka memiliki anak lagi maka hal itu akan membutuhkan biaya yang lebih lagi.

Kondisi sosial ekonomi masyarakat dan tingkat kemajuan teknologinya terhadap implementasi program Pendewasaan Usia Perkawinan (PUP) di Kecamatan Amuntai dapat disimpukan bahwa belum optimal, hal ini dikarenakan tingkat pendidikan dan pekerjaan yang rendah dapat memengaruhi tingkat keberhasilan implementasi, sebab pehamaman dan kepercayaan terhadap program Pendewasaan Usia Perkawinan (PUP) yang kurang. Disamping itu, tingkat kemajuan teknologi yang belum merata dan belum sepenuhnya dipahami oleh seluruh masyarakat dapat mempersulit proses sosialisasi dan implementasi program PUP ini.

\section{Faktor Penghambat Implementasi Program Pendewasaan Usia Perkawinan (PUP) di Kecamatan Amuntai Selatan Kabupaten Hulu Sungai Utara}

\section{Keanekaragaman Sifat Kelompok Sasaran}

Proses implementasi program akan lebih mudah dilaksanakan juga kelompok target sasarannya tidak berbeda-beda sifat dan pemikirannya terhadap suatu program. Suatu program akan relatif mudah diimplementasikan apabila kelompok sasarannya adalah homogen. Sebaliknya, apabila kelompok sasarannya heterogen, maka implementasi program akan relatif lebih sulit, karena tingkat pemahaman setiap anggota kelompok sasaran terhadap program relatif berbeda. Apabila kelompok sasaran memiliki sifat, pandangan serta pendapat yang relatif berbeda dalam menyikapi sesuatu program, maka hal ini cenderung akan menjadi penghambat suatu implementasi program itu sendiri. Hal ini dikarenakan setiap anggota (masyarakat) dalam kelompok sasaran tersebut memiliki tingkat pemahaman yang berbeda, ada 
yang mudah untuk menerima, ada yang perlu diberikan penjelasan yang rinci dulu baru mengerti dan juga ada yang menolak dengan alasan yang bermacam-macam.

Adapun kelompok sasaran dari program Pendewasaan Usia Perkawinan ini adalah para remaja baik laki-laki atau perempuan yang nantinya akan melangsungkan pernikahan dan para orangtua yang memilki remaja yang dibina dalam persiapan untuk berumah tangga. 2 kelompok sasaran ini merupakan orang-orang yang cenderung memiliki perbedaan pemikiran dalam menghadapi suatu masalah. Remaja yang terdidik dan modern akan relatif mudah menerima program pembaruan, dibanding orangtua yang memilki zaman yang berbeda dengan anak remajanya dimana kebanyakan pemikiran orang tua ini masih bersifat tradisional dan cenderung acuh terhadap program-program pembaruan. Tugas program PUP inilah yang bertujuan menyamakan pandangan dan pemikiran antara si remaja dan orang tua untuk samasama dapat merubah pola pikir tentang pernikahan dini.

\section{Ketidakjelasan Isi Program}

Di dalam sebuah kebijakan atau program yang akan diimplementasikan ke masyarakat akan selalu ada faktor-faktor yang memengaruhi proses implementasi program tersebut, entah itu memengaruhi keberhasilan atau yang menghambat proses implementasi tersebut. Semakin jelas dan rinci isi sebuah kebijakan maka akan semakin mudah diimplementasikan kebijakan tersebut, hal ini karena implementor mudah memahami dan menterjemahkan dalam tindakan nyata kepada kelompok sasaran. Sebaliknya, jika isi kebijakan adanya ketidakjelasan kebijakan ini berarti adanya potensi lahirnya distorsi atau penyimpangan dalam implementasi kebijakan. Dari hal ini dapat diketahui bahwa sebuah kejelasan isi dalam program tersebut dapat memengaruhi implementasi sebuah program.

Adapun isi dalam program Pendewasaan Usia Perkawinan (PUP) ini adalah upaya meningkatkan usia perkawinan masyarakat ke usia yang lebih matang dan ideal yaitu pada umur minimal menikah 21 tahun perempuan dan laki-laki miminal 25 tahun. Selain itu program ini juga memberitahukan tentang resiko-resiko nikah dini atau terlalu muda, baik dari segi ekonomi, sosial budaya dan kesehatannya.

\section{KESIMPULAN}

Hasil penelitian dan pembahasan, maka dapat diambil kesimpulan sebagai berikut.

1. Implementasi Program Pendewasaan Usia Perkawinan (PUP) di Kecamatan Amuntai Selatan Kabupaten Hulu Sungai Utara belum berjalan optimal dikarenakan beberapa indikator di antaranya sebagai berikut. Pertama, Kesulitan teknis masalah yang bersangkutan termasuk dalam sesuatu hal yang sulit diatasi dan masa-masa yang dianjurkan dalam program PUP dirasa sulit untuk diikuti masyarakat, sehingga membuat implementasi program belum berjalan optimal. Kedua, Tingkat kemajemukan (keanekaragaman) dari kelompok sasaran yang bermacam-macam pemikiran, pandangan dan tingkat pehamaman terhadap suatu program, sehingga hal ini membuat implementasi program belum berjalan optimal. menjarangkan kehamilan serta mengakhiri kehamilan yang cenderung sulit, sehingga membuat implementasi program belum optimal. Kejelasan isi kebijakan masih membuat masyarakat bingung sehingga menimbulkan distorsi di masyarakat, hal ini membuat implementasi program masih belum optimal. Lingkungan Kebijakan, kondisi sosial ekonomi (pekerjaan dan pendidikan) masyarakat yang masih rendah. pola pikir yang tertutup dan gaya hidup tradisional serta kemajuan teknologi yang masih rendah, hal ini membuat implementasi program belum berjalan optimal. Dukungan publik terhadap kebijakan yang masih kurang, sehingga membuat implementasi program belum berjalan optimal. Ketiga, Sikap dari kelompok pemilih yang masih ada menilai program ini tidak terlalu penting, sehingga membuat implementasi program belum berjalan optimal. Keempat, Tingkat komitmen dan 
keterampilan aparat dan implementor belum optimal dikarenakan upaya yang dilakukan dalam pengumpulan data yang berhubungan dengan program masih banyak belum dimiliki oleh petugas.

2. Faktor penghambat Implementasi Program Pendewasaan Usia Perkawinan (PUP) di Kecamatan Amuntai Selatan Kabupaten Hulu Sungai Utara antara lain: Keanekaragaman sifat dari kelompok sasaran membuat implementasi program Pendewasaan Usia Perkawinan (PUP) di Kecamatan Amuntai Selatan Kabupaten Hulu Sungai belum sepenuhnya berjalan optimal dikarenakan perbedaan pandangan dalam menyikapi program pembaruan

\section{SARAN}

1. Kepala Dinas Pengendalian Penduduk dan Keluarga Berencana (DPPKB) Kabupaten Hulu Sungai Utara diharapkan dapat menyediakan alokasi dana khusus Program Pendewasaan Usia Perkawinan (PUP), membentuk Pusat Informasi dan Konseling Remaja (PIK-R) secara merata di setiap desa di Kecamatan Amuntai Selatan, meningkatkan alokasi dana kelompok Pusat Informasi dan Konseling Remaja (PIK-R) dan Bina Keluarga Remaja (BKR) serta menegaskan kepada Balai Penyuluhan Keluarga Berencana (BPKP) bahwa data seputar program PUP sangatlah penting untuk dikumpulkan.

2. Kepala Desa setempat diharapkan untuk senantiasa mendukung dan ikut memasyarakatkan Program Pendewasaan Usia Perkawinan (PUP) di desanya masing-masing serta dapat memaksimalkan alokasi dana desa untuk membantu pelaksanaan Program Pendewasaan Usia Perkawinan (PUP) serta kelompok pendukungnya seperti Pusat Informasi dan Konseling Remaja (PIK-R) dan Bina Keluarga Remaja (BKR)

3. Instansi-instansi lintas sektor yang terkait seperti Kantor Urusan Agama (KUA) Kecamatan Amuntai Selatan, Puskesmas Kecamatan Amuntai Selatan, Dinas Pemberdayaan Perempuan dan Perlindungan Anak (DP3A) Kabupaten Hulu Sungai Utara, serta lembaga-lembaga yang secara tidak langsung terkait, diharapkan selalu meningkatkan komitmen, kolaborasi, dukungan dan kontribusinya dalam pencegahan pernikahan dini baik melalui program Pendewasaan Usia Perkawinan (PUP) yaitu menuda perkawinan dan kehamilan, menjarangkan masa kehamilan dan mengakhiri kehamilan/berhenti untuk punya anak lagi maupun melalui program lainnya di masing-masing instansi

\section{DAFTAR PUSTAKA}

[1] Affrian, R. (2019). Implementasi Kebijakan Pemenuhan Hak Orang Dengan Gangguan Jiwa Di Kabupaten Hulu Sungai Utara. Al'iidara Balad, 1(1), 85-95.

[2] Affrian, R., \& Walinda, R. (2020). Komunikasi Program Imunisasi Vaksin Measles Rubella Puskesmas Haur Gading Kabupaten Hulu Sungai Utara. Jurnal Administrasi Politik dan Sosial, 1(1), $42-50$.

[3] Anggara, Sahya. 2015. Metode Penelitian Administrasi. Bandung: CV. Pustaka Setia. - Hal. 57

[4] Agustino,Leo. 2016. Dasar-Dasar Kebijakan Publik, Bandung:Alfabeta - Hal. 16, 17, 25,26 
[5] Anonim. (2019). Profil Desa Simpang Empat Tahun 2019. Pemerintahan Desa Simpang Empat Kecamatan Amuntai Selatan Kabupaten Hulu Sungai Utara - Hal 161, 164

[6] Anonim. (2019). Profil Desa Kayakah Tahun 2019. Pemerintahan Desa Kayakah Kecamatan Amuntai Selatan Kabupaten Hulu Sungai Utara - Hal. 162, 165

[7] Anonim. (2019). Profil Desa Jumba Tahun 2019. Pemerintahan Desa Jumba Kecamatan Amuntai Selatan Kabupaten Hulu Sungai Utara - Hal. 162, 165

[8] Arfianty Desy. 2019. Antara Award 2018 Atas Pemkab HSU Berhasil Tekan Angka Pernikahan Dini. Kanal Kalimantan.

[9] Jamaika, Anisa Binta. 2015. Implementasi Kebijakan terhadap Program Pendewasaan Usia Perkawinan di Kabupaten Bondowoso. Skripsi. Fakultas Kesehatan Masyarakat, Bagian Administrasi dan Kebijakan Kesehatan, Universitas Jember, Jember.

[10] Fadjar, Mulyadi. 2018. Jurnal Pendewasaan Usia Perkawinan. Dinas Kesehatan Provinsi Nusa Tenggara Barat.

[11] Fischer,Frank. Et al. 2015. Analisis Kebijakan Publik (Teori, Politik dan Metode), Bandung: Nusa Media - Hal. 14

[12] Gunawan,Imam, 2015. Metode Peneltian Kualitatif Teori dan Praktik, cetakan ke-1. Jakarta:Bumi Aksara - Hal. 57, 62

[13] Mardiyanti, Ika. 2015. Kejadian Keguguran ditinjau dari Umur Ibudi BPS Ita Ariani Sidoarjo. Fakultas Keperawatan dan Kebidanan Universitas Nahdatul Ulama Surabaya. Jurnal Ilmiah Kesehatan, Vol. 8, No. 2, Agustus 2015, halaman 213-220.

[14] Pasolong, Harbani. 2007. Teori Administrasi Publik. Bandung: Alfabeta - Hal. 39

[15] Suaib, Muhammad Ridha. 2016. Pengantar Kebijakan Publik : dari Administrasi Negara, Kebijkakan Publik, Pelayanan Publik, Good Governace, Hingga Implementasi Kebijakan. Yogyakarta: Calpulis - Hal. 14, 15

[16] Subarsono. 2015. Analisis Kebijakan Publik (Konsep, Teori dan Aplikasi). Yogyakarta:Pustaka Belajar. - Hal. 6, 16, 18, 27-37, 55, 61, 90

[17] Sugiyono. 2015. Metode Penelitan Pendidikan ( Pendekatan Kuantitatif, Kualitatif dan R\&D. Bandung: Alfabeta - Hal. 63, 64.

[18] Undang-Undang Nomor 52 Tahun 2009 Tentang Perkembangan Kependudukan Pembangunan Keluarga. - Hal. 41, 53

[19] Undang-Undang Republik Indonesia Nomor 16 Tahun 2019 tentang Perubahan Atas UndangUndang Nomor 1 Tahun 1974. - Hal. 89, 97 